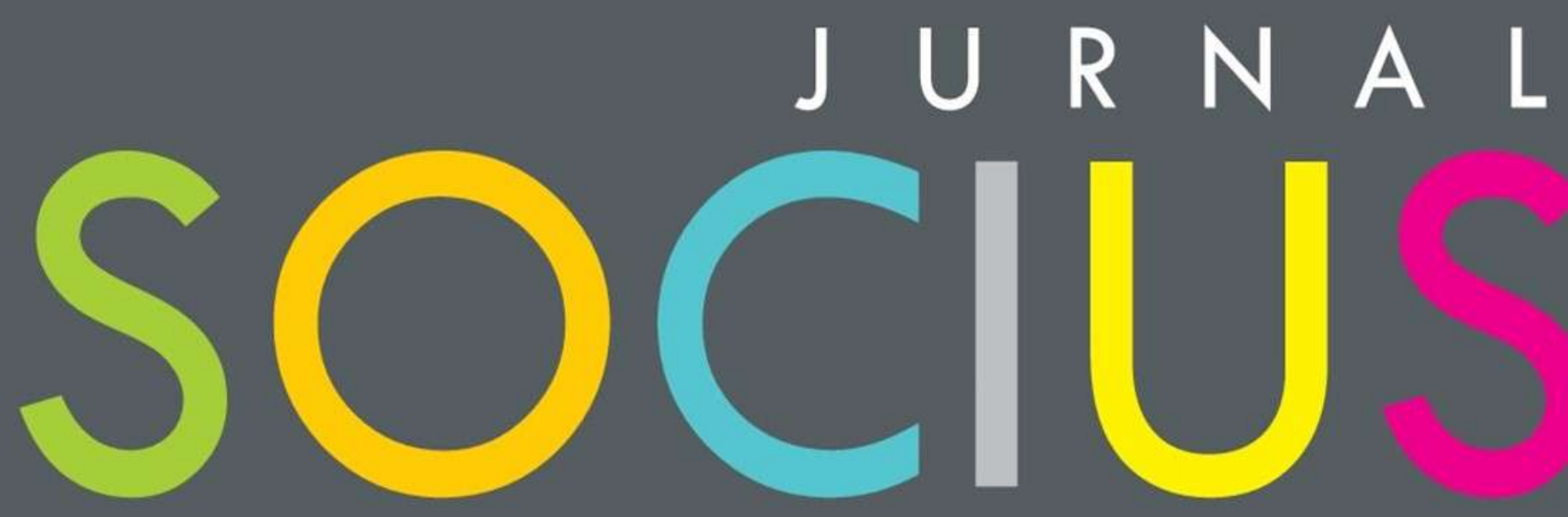

Journal of Sociology Research and Education

DITERBITKAN OLEH :

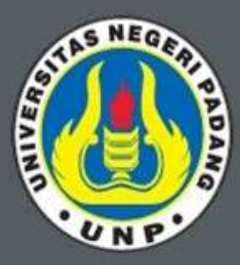

LABOR JURUSAN SOSIOLOGI FAKULTAS ILMU SOSIAL UNIVERSITAS NEGERI PADANG

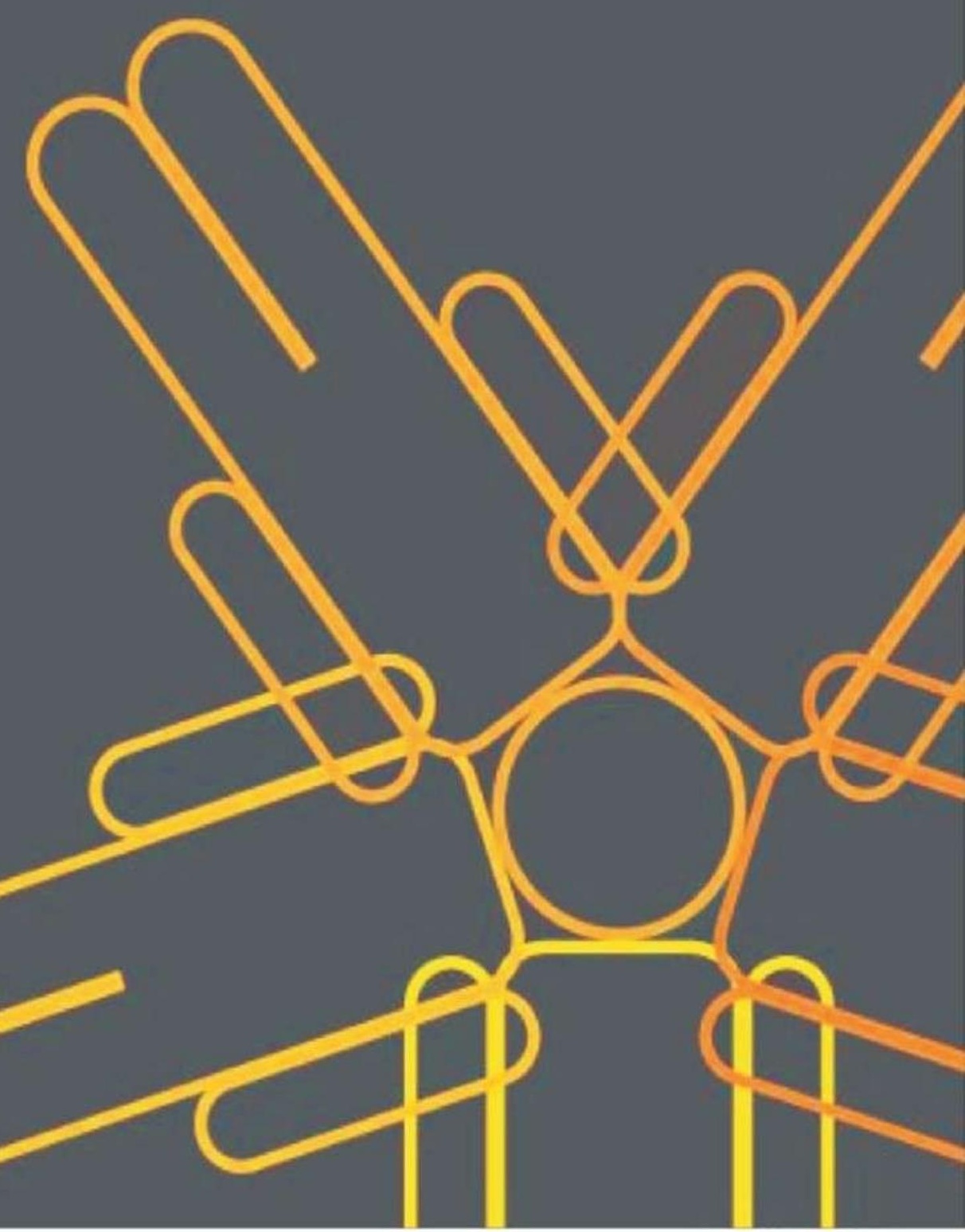




\section{SOCIUS}

Vol. 6, No.2, Th. 2019

ISSN : 2356-4180 (cetak)

2442-8663 (online)

\begin{tabular}{|c|c|}
\hline $\begin{array}{c}\text { REDAKSI } \\
\text { JURNAL SOCIUS }\end{array}$ & DAFTAR ISI \\
\hline $\begin{array}{c}\text { Editor in Chief : } \\
\text { Selinaswati } \\
\text { Managing Editor : } \\
\text { Erda Fitriani } \\
\text { Editorial Board: } \\
\text { Eka Vidya Putra } \\
\text { Desy Mardiah } \\
\text { Ike Sylvia } \\
\text { Erianjoni } \\
\text { Mohammad Isa Gautama } \\
\text { Reno Fernandes }\end{array}$ & $\begin{array}{c}\text { Mutia Kahana, Junaidi } \\
\text { Pengaruh Penerapan Model Konsiderasi Terhadap Pembentukan } \\
\text { Sikap Siswa dalam Pembelajaran Sosiologi di Kelas XI IPS SMA } \\
\text { Adabiah Padang } \\
\text { Halaman 62-69 } \\
\text { Reno Fernandes } \\
\text { Revolusi 4.0 } \\
\text { Halaman } 70-80\end{array}$ \\
\hline $\begin{array}{c}\text { Reviewer: } \\
\text { Rebecca Fanany } \\
\text { Elly Malihah } \\
\text { (Deakin University , } \\
\text { (Universitas Pendidikan Indonesia, Indonesia) } \\
\text { Nur Hidayat Sardini } \\
\text { (Universitas Diponegoro, Indonesia) } \\
\text { Ubedilah Badrun } \\
\text { ( Universitas Negeri Jakarta, Indonesia) } \\
\text { Moh. Yasir Alimi } \\
\text { (Universitas Negeri Semarang, Indonesia) } \\
\text { Ferdinand Kerebungu } \\
\text { (Universitas Negeri Menado, Indonesia) } \\
\text { Jendrius } \\
\text { (Universitas Andalas, Indonesia) } \\
\text { Lucky Zamzami } \\
\text { (Universitas Andalas, Indonesia) } \\
\text { Adri Febrianto } \\
\text { (Universitas Negeri Padang, Indonesia) } \\
\text { Ikhwan } \\
\text { (Universitas Negeri Padang, Indonesia) } \\
\text { Aisiah } \\
\text { (Universitas Negeri Padang, Indonesia) } \\
\text { Junaidi Indrawadi } \\
\text { (Universitas Negeri Padang, Indonesia) } \\
\text { Sadri Chaniago } \\
\text { (Universitas Andalas, Indonesia) }\end{array}$ & $\begin{array}{c}\text { Andreas Dego, Yoseph D.A. Santie, Sem Deehop, Ferdinand } \\
\text { Kerebungu } \\
\text { Analisis Kompetensi Pedagogik Guru IPS di SMP Negeri } 1 \text { Kabupaten } \\
\text { Pulau Morotai } \\
\text { Halaman } 81-89 \\
\text { Yuyut Chandra, Aidinil Zetra, Ria Ariyany } \\
\text { LKAAM Kota Solok) } \\
\text { Halaman 90-102 } \\
\text { Demokrasi Deliberatif Masyarakat Minangkabau (Studi Kasus: } \\
\text { Ike Sylvia, Syafri Anwar, Khairani } \\
\text { Pengembangan Instrumen Penilaian Autentik Berbasis Pendekatan } \\
\text { Authentic Inquiry Learning Pada Mata Pelajaran Sosiologi di Sekolah } \\
\text { Menengah Atas } \\
\text { Halaman 103-120 } \\
\text { Pawennari Hijjang, Lia Amelia } \\
\text { Assajingeng: Politik Kekerabatan di Pilkada Kabupaten Bone (Analisis } \\
\text { Antropologi Politik) } \\
\text { Halaman 121-134 }\end{array}$ \\
\hline $\begin{array}{c}\text { Layout Editor : } \\
\text { Rhavy Ferdyan, S.Pd. } \\
\text { Technical Support: } \\
\text { Rudi Mahesa, A.Md. } \\
\text { Alamat Redaksi: } \\
\text { Jurusan Sosiologi FIS UNP } \\
\text { Jl. Prof.Dr.Hamka } \\
\text { Kampus UNP Air Tawar } \\
\text { e-mail: sosan@ fis.unp.ac.id } \\
\text { Penerbit } \\
\text { Labor Jurusan Sosiologi } \\
\text { Universitas Negeri Padang }\end{array}$ & \\
\hline
\end{tabular}




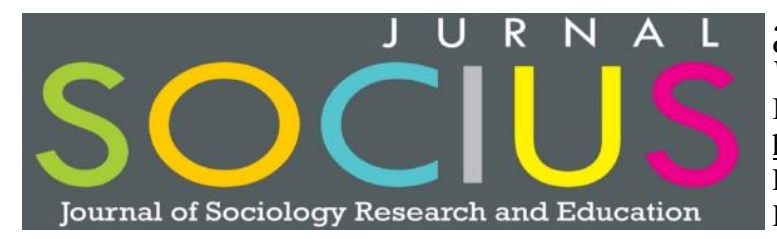

Jurnal Socius: Journal of Sociology Research and Education Vol.6, No.2, Th. 2019

ISSN: Online 2442-8663 - Print 2356-4180

http://socius.ppj.unp.ac.id/index.php/socius

Email: socius@ppj.unp.ac.id

DOI: https://doi.org/10.24036/scs.v6i2.151

\title{
Analisis Kompetensi Pedagogik Guru IPS di SMP Negeri 1 Kabupaten Pulau Morotai
}

\author{
Andreas Dego', Yoseph D. A Santie ${ }^{2}$, Sem Dehoop ${ }^{3}$, Ferdinand Kerebungu ${ }^{4}$ \\ 1,2,3,4 Universitas Negeri Manado \\ Email: andreasdego04@gmail.com
}

\begin{abstract}
Abstrak
Permasalahan dalam penelitian ini adalah ketidakmampuan guru IPS dalam mengembangkan kompetensi pedagogik guru IPS pada SMP Negeri 1 Kabupaten Pulau Morotai dalam menyusun rancangan pembelajaran. Tujuan penelitian ini menganalisis kemampuan kompetensi pedagogik guru mata pelajaran IPS di SMP Negeri I Kabupaten Pulau Morotai dalam pelaksanaan proses pembelajaran. Metode penelitian ini menggunakan metode kualitatif, teknik pengumpulan data dilakukan melalui observasi langsung, wawancara, dan dokumentasi. Sedangkan teknik analisis data menggunakan teknik analisis interaktif yaitu reduksi data, penyajian data, dan penarikan kesimpulan (Miles dan Huberman). Hasil penelitian menunjukkan bahwa kompetensi pedagogik guru IPS di SMP Negeri 1 Kabupaten Pulau Morotai dalam melaksanakan pembelajaran di kelas cukup baik, dari lima indikator kompetensi pedagogik, hanya satu indikator yang belum sepenuhnya dikuasai oleh guru IPS yaitu pemahaman terhadap peserta didik, guru tidak benar-benar memahami karakteristik peserta siswa dan juga manajemen kelas yang perlu ditingkatkan lagi, sedangkan dalam indikator perancangan pembelajaran, menerapkan pembelajaran, mengevaluasi hasil belajar, mengembangkan siswa untuk mengaktualisasikan berbagai potensi yang dimiliki, guru telah memenuhi keempat indikator dengan cukup baik.
\end{abstract}

Kata kunci: Kompetensi Pedagogik, Guru IPS, SMP Negeri 1 Kabupaten Pulau Morotai

\section{Abstract}

The problem of this study is the inability of the IPS teacher to develop pedagogical competence in SMP Negeri 1 Pulau Morotai Regency in preparing learning designs in class. The purpose of this study was to analyze the IPS teacher's pedagogical competency skills when implementing learning. The research method used in this study is a qualitative method, with data collection techniques direct observation (observation), interviews, and documentation. While the data analysis technique uses interactive analysis techniques, namely data reduction, data presentation, and concluding, the results showed that the IPS teacher's pedagogical competence in SMP Negeri 1 Pulau Morotai Regency in implementing learning in the classroom was quite good. Out of the five indicators of pedagogical competence, only one indicator had not mastered by the IPS teacher, namely Understanding students. The teacher did not understand the participants' characteristics students and also class management that needs to be improved. While in the indicators of learning design, implementing learning, evaluating learning outcomes, developing students to actualize the various potentials owned, the teacher has fulfilled all four indicators well.

Keywords: Competence Pedagogic, Social Sciences Teacher, SMP Negeri 1 Kabupaten Pulau Morotai

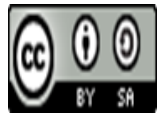

Received: November 7, 2019 Revised: December 30, 2019 Available Online: December 31, 2019 


\section{Pendahuluan}

Dalam mewujudkan tujuan pendidikan nasional, pendidik dianggap mampu untuk mewujudkan tujuan pendidikan Nasional yaitu suatu kemampuan untuk mengembangkan potensi perserta didik agar menjadi manusia yang beriman dan bertakwa kepada Tuhan yang Maha Esa, serta mampu menuntun peserta didiknya menjadi insan yang berilmu, cakap, kreatif dan mandiri, sehingga menjadi warga negara yang demokratis serta bertanggungjawab (UU Sisdiknas nomor 20 tahun 2003). Guru adalah pendidik profesional dengan tugas utama mendidik, mengajar, membimbing, mengarahkan, melatih, menilai dan mengevaluasi peserta didik .(UU nomor 14 tahun 2015 tentang Guru dan Dosen). Untuk itu seorang guru dalam menjalankan tugasnya dengan baik dan profesional, dituntut agar memiliki empat kompetensi, yakni kompetensi pedagogik, kompetensi profesional, kompetensi kepribadian, dan kompetensi sosial. (UU nomor 14 tahun 2015 tentang Guru dan Dosen). Dalam proses merealisasikan tugas dan tanggungjawabnya sebagai seorang guru yang profesional diperhadapkan dengan berbagai tantangan terutama dalam mengimplementasikan empat (4) kompetensi guru, khususnya kompetensi pedagogik. Kemampuan guru dalam merancang bahan ajar hingga terselesaikannya RPP, terutama bagi guru IPS, acapkali hanya mengambil RPP dari teman atau mengunduh dari internet tanpa memperhatikan kondisi lingkungan sosial dan alam di sekolahnya. Hasil penelitian terdahulu yang relevan yang dilaksanakan oleh Danald S. S. Santoso dan Lilis Irawati tentang Kompetensi Pedagogik Guru SMP Negeri 2 Kaloran Kecamatan Kaloran Kabupaten Temanggung, bahwa mereka lebih menitikberatkan pada Permendiknas No. 16 Tahun 2007 mengenai Standar Guru, dan "hasil penelitiannya bahwa dari 10 (sepuluh) komponen Standar kompetensi guru, hanya 3 (tiga) komponen yang belum dimiliki dengan baik yaitu kompetensi menyelenggarakan pembelajaran yang berkualitas; kompetensi memanfaatkan teknologi pembelajaran; dan kompetensi berkomunikasi dengan empatik, efektif dan satuan terhadap peserta didik. Hal ini terbukti dengan adanya guru yang lebih sering menggunakan metode belajar dengan ceramah dan diskusi sehingga siswa yang tidak konsentrasi dan tidak memiliki daya tarik untuk belajar". Dengan demikian bahwa kompetensi Pedagogik guru belum sepenuhnya dilaksnakan dengan baik, hal serupa juga terjadi pada Guru IPS di SMP Negeri I Kabupeten Pulau Morotai

Guru IPS di SMP Negeri I Kabupaten Pulau Morotai, hingga pada saat penelitian ini dilaksanakan, diperhadapkan dengan problema mendasar yaitu mereka tidak mampu untuk menjadi teladan bagi peserta didiknya, bahkan muncul gejala terjadinya kemerosotan harkat dan martabat guru, kondisi yang demikian bertentangan dengan amanat UU Sisdiknas yang menyatakan bahwa guru harus beriman dan bertakwa kepada Tuhan Yang Maha Esa dan berahkhlak mulia. Hal ini disebabkan karena semangat dedikatif guru menurun, rendah, belum menjamin terlaksananya pelayanan profesi secara terarah dan pengakuan secara sehat dari berbagai pihak. Ini terjadi karena sebagaian guru menampilkan citra yang kurang professional, Nurhayati Djamas (dalam Ahmad Fatah Yasin,2011).

Proses pembelajaran merupakan suatu proses yang dijalankan dan berhubungan satu sama lain, proses tersebut mulai dari penyusunan rencana pembelajaran, pelaksanaan pembelajaran, evaluasi hasil belajar dan pengembangan potensi yang dimiliki oleh peserta didik. Salah satu poin terpenting dalam kompetensi pedagogik ialah penyusunan rencana pembelajaran (Planing) yang merupakan salah satu fungsi utama yang harus dilakukan oleh seorang guru dalam melaksanakan proses pembelajaran. Dengan adanya perencanaan yang baik dan cermat dalam memperhitungkan apa yang menjadi kebutuhan peserta didik, tujuan isi dan bahan, sehingga proses pembelajaran terarah dan terorganisir dengan baik, sehingga akan tercapai tujuan pembelajaran yang kita inginkan sesuai dengan perencanaan (Planing).

Jurnal Socius: Journal of Sociology Research and Education Vol. 6, No.2, Th. 2019 
Untuk mencapai suatu proses pembelajaran secara optimal, diperlukan kemampuan sorang guru dimulai dari kesiapannnya untuk menyampaikan materi pembelajaran, maka seorang guru dituntut untuk memiliki kompetensi dalam mengajar terutama kemampuan penguasaan kompetensi pedagogik. Dengan memiliki kemampauan kompetensi pedagogik, yaitu suatu kemampuan yang berkaitan langsung dengan kemampuan dalam perencanaan pembelajaran, kemampuan dalam memahami karakteristik peserta didik, kemampuan dalam melaksanakan proses pembelajaran, kemampuan dalam mengevaluasi hasil belajar, dan juga kemampuan guru dalam mengembangkan potensi yang dimiliki oleh peserta didik.

Terkait dengan Kompetensi Pedagogik Guru IPS di SMP Negeri 1 Kabupaten Pulau Morotai, guru jarang membuat perencanaan pembelajaran, guru membuat rencana pembelajaran yang baik tidak sekedar oleh karena adanya pengawasan dari dinas terkait dalam hal ini Dinas Pendidikan yang swaktu-waktu melaksanakan supervisi bagi setiap guru dalam melaksanakan tugasnya. Dalam kegiatan proses belajar mengajar yang dilakukan oleh guru IPS, pada umumnya guru IPS di SMP Negeri I Kabupaten Pulau Morotai hanya menyediakan buku paket bagi peserta didiknya tanpa disertai dengan pemberian penjelasan tentang materi dalam buku teks tersebut, dan guru hanya memerintahkan peserta didiknya untuk mencatat materi pelajaran sesuai dengan yang tercantum dalam RPP.

Dalam proses pembelajaran juga guru terlalu kaku, tidak mengedepankan prinsip-prinsip kemanusiaan terhadap peserta didik. Pendidikan hanya sebatas pada pengajaran yang hanya ranah kongnitif, sehingga capaian pembelajaran hanya sebatas pada kegiatan mencatat, menghafal, dan mengerjakan soal-soal, dan kegiatan semacam ini tidak akan mencampai pada tujuan pembelajaran IPS yaitu pembentukan sikap dan perubahan karakter peserta didik, dan juga tidak terbentuknya hubungan yang humanis antara pendidik dan peserta didik.

Terkait dengan itu, masalah yang peneliti temukan adalah (1) Kurangnya strategi/metode yang dipakai dalam pelaksanaan pembelajaran, (2) Proses pembelajaran yang tidak terlalu menekan pada kebebasan berpikir siswa, (3) Pelaksanaan proses pembelajaran yang tidak manusiawi, (4) Pelaksanaan pembelajaran yang bersifat intruksional-edukatif tidak terealisasi secara efektif, (5) Rendanya kemampuan guru IPS dalam menyusun RPP, dan (6) Kurangnya kemampuan guru IPS dalam melaksanakan mengevaluasi hasil belajar siswa

Berkaitan dengan tujuan penelitian yaitu menganalisis kompetensi pedagogik Guru IPS dalam pelaksanaan proses pembelajaran di SMP Negeri 1 Kabupaten Pulau Morotai, maka permasalahan dalam penelitian ini adalah ketidakmampuan guru IPS dalam mengembangkan kompetensi pedagogik dalam menyusun rancangan pembelajaran pada SMP Negeri 1 Pulau Morotai. Sehubungan dengan masalah dan tujuan penelitian maka dalam penelitian ini menggunakan konsep yang disampaikan oleh Nur Irwanto guna menjawab persoalan mendasar yang berkaitan dengan kompetensi pedagogik di SMP Negeri 1 Kabupaten Pulau Morotai. Nur Irwanto (2016) menjelaskan bahwa, kompetensi pedagogik merupakan kompetensi intruksional-edukatif (mengajar dan mendidik) yang esensial dan fundamental bagi guru dalam pelaksanaan tugas keprofesionalannya, terutama tugas mendidik, mengajar, membimbing, melatih, menilai, dan mengevaluasi peserta didik.

\section{Metode Penelitian}

Pendekatan penelitian yang digunakan dalam penelitian ini adalah metode kualitatif. Sumber data atau subjek penelitian adalah Guru IPS di SMP Negeri 1 Kabupaten Pulau Morotai. Proses pengumpulan data dilakukan melalui observasi, wawancara terstruktur, dan 
dokumentasi. Sedangkan data yang diperoleh dianalisis dengan menggunakan teknik analisis interaktif menurut Miles dan Huberman.

\section{Hasil dan Pembahasan}

\section{Hasil Penelitian}

Berdasarkan data hasil penelitian tentang kemampuan Kompetensi pedagogik guru IPS terdapat 5 (lima) indikator yang menonjol; indikator-indikator tersebut adalah:

\section{Memahami karakteristik peserta didik}

Sesuai dengan hasil penelitian yang didapatkan berdasarkan wawancara dan juga hasil pengamatan langsung, Maka dapat dikatakan kemampuan guru IPS dalam memahami karakteristik peserta didik belum terlalu optimal, hal ini didasarkan ketika proses pembelajaran masih ada juga peserta didik ribut ketika proses pembelajaran, guru tidak terlalu memberikan kesempatan yang sama kepada peserta didik untuk berpartisipasi aktif dalam proses pembelajaran, dan tidak terlalu memahami apa yang menjadi kelemahan dari peserta didik, baik dari segi kemampuan dan juga secara fisik. Oleh karena itu maka, dapat disimpulkan bahwa kemampuan guru dalam memahami karakteristik peserta didik belum terlalu optimal dan perlunya dalam meningkatkan kemampuanya.

\section{Perancangan pembelajaran}

Sesuai hasil penelitian menunjukkan Bahwa, kemampuan guru dalam perancangan pembelajaran cukup baik, hal ini didasarkan pada saat proses pembelajaran, guru sudah menyusun program pembelajaran dengan baik sesuai dengan silabus dan juga memperhatikan materi ajar yang sesuai tingkat kemampuan belajar siswa agar tujuan pembelajaran dapat tercapai. Oleh karena itu, indikator perancangan pembelajaran dapat dikatakan cukup baik.

\section{Melaksanakan pembelajaran}

Sesuai hasil penelitian menunjukkan bahwa dalam proses pembelajaran, guru melakukan aktivitas pembelajaran sesuai dengan rancangan yang disusun secara lengkap, dapat dilihat dalam rencana pelaksanaan pembelajaran, dan dalam melaksanakan proses pembelajaran guru selalu berkomunikasi aktif dengan peserta didik, dan juga dalam pelaksanaan proses pembelajaran guru membantu/membimbing proses belajar peserta didik dan bukan tujuan untuk menguji sehingga proses pembelajaran peserta didik merasa nyaman dan tidak tertekan. Terkait dengan hasil penelitian ini, Maka, dapat disimpulkan bahwa kemampuan dalam Melaksanakan pembelajaran tergolong baik.

\section{Evaluasi hasil belajar}

Sesuai hasil penelitian menunjukkan bahwa guru selalu melakukan evaluasi hasil belajar, dan selalu memanfaatkan hasil evaluasi tersebut untuk dijadikan pedoman dalam menyusun bahan pembelajaran yang dilakunan selanjutnya. Melaksanakan penilaian dengan berbagai teknik dan jenis penilaian, selain penilain formal yang dilakukan oleh sekolah. Mengidentifikasi hasil penilaian untuk mengetahui topik yang sulit sehingga dapat diketahui kekuatan dan kelemahan masing-masing peserta didik demi keperluan remedial. Terkait dengan hasil penelitian ini maka, dapat dikatan bahwa, kemampuan guru dalam mengevaluasi dapat golongkan cukup baik

\section{Mengembangkan potensi peserta didik untuk mengaktualisasikan berbagai potensi yang dimilikinya}

Sesuai hasil penelitian menunjukkan bahwa, dalam mengembangkan potensi peserta didik, guru melaksanakan aktivitas pembelajaran yang mendorong peserta didik untuk belajar 
sesuai dengan kemampuan dan pola belajar masing-masing. Dalam proses pembelajaran juga guru selalu memberikan ruang bagi peserta didik untuk berpartisipasi dalam proses tersebut dengan tujuan agar peserta didik dapat mengembangkan kemampuan intelektual dan juga kemampuan mental, guru juga mengindentifkasi bakat dan minat dari peserta didik, sehingga guru mendorong, memotivasi, dan membimbing sesuai dengan bakat dan minat masingmasing. Terkait dengan ini, maka, kemampuan dalam mengembangkan potensi peserta didik, dapat dikatakan cukup baik.

\section{Pembahasan}

\section{Mehamahami karakteristk peserta didik}

E Mulyasa (2009) menjelaskan bahwa peserta didik adalah setiap orang yang menerima pengaruh dari seorang guru atau sekelompok orang yang menjalankan kegiatan pendidikan. Tujuan guru mengawal siswa-siswanya adalah agar guru dapat membantu pertumbuhan dan perkembangan secara efektif, menentukan materi yang akan diberikan, menggunakan prosedur mengajar yang serasi, mengadakan diagnosis atas kesulitan belajar yang dialami oleh siswa, dan kegiatan-kegiatan guru lainnya yang berkaitan dengan individu siswa. Dalam memahami siswa, guru perlu memberikan perhatian khusus pada perbedaan individual anak didik.

Berkaitan dengan penjelasan yang disampaikan oleh E Mulyasa (2009), sebagai pendidik harus mampu dalam memahami karakteristik dari peserta didik, karena kemampuan ini sangat urgen dalam proses pendidikan yang kita laksanakan dikelas, pendidik seharusnya lebih aktif dalam mengawasi peserta didik dalam rangka untuk menumbuhkembangkan potensi dan juga mengawasi pertumbuhan dan perkembangan dari peserta didik, sebagai pendidik juga harus mampu dalam melihat, memilih materi yang sesuai dengan kebutuhan dari peserta didik.

Terkait dengan penjelasan teori di atas, maka peneliti menemukan data dilapangan bahwa, guru IPS di SMP Negeri 1 Kabupaten Pulau Morotai sudah memahami karakteristik peserta didik, hal ini dibuktikan dengan jawaban yang disampaikan oleh informan bahwa dalam setiap proses pembelajaran yang dilakukan oleh guru IPS selalu melakukan pendekatan baik itu pendekatan secara individu dan juga kelompok pada saat proses pembelajaran berlangsung, dengan tujuan membantu peserta didik yang mengalami kesulitan belajar. Dalam pelaksanaan proses pembelajaran juga, guru selalu mengatur tempat duduk dari peserta didik, dan peserta didik yang nakal dipindahkan kebangku depan dengan tujuan agar peserta didik tersebut tidak mengganggu peserta didik yang lain. Terkait dengan hasil wawacara tersebut didukung juga dengan hasil pengamatan peneliti terhadap guru IPS pada saat pelaksanaan pembelajaran, bahwa guru memahami karakteristi peserta didik, dengan menggunakan pendekatanpendekatan, baik itu secara pribadi dan juga kelompok dalam mendiagnosa apa yang menjadi kesulitan peserta didik dalam proses pembelajaran tersebut. Bukan hanya itu saja, sebagai pendidik juga harus mampu membantu pertumbuhan dan perkembangan peserta didik, dan melakukan diagnosa, apa yang menjadi kebutuhan dan kesulitan belajar yang dialami oleh peserta didik.

Dari penjelasan teori yang disampaikan oleh E. Mulyasa (2009) Sejatinya, seorang guru dituntut harus mampu dalam memahami karakteristik peserta didik, dengan kemampuan pemahaman karakteristik peserta didik dan juga pengelolaan proses pembelajaran yang baik merupakan hal yang urgen dalam melaksanakan proses pembelajaran terhadap peserta didik.

\section{Perancangan pembelajaran}

Winarno dan Djuniarto (2003) menjelaskan bahwa pembelajaran merupakan catatancatatan hasil pemikiran awal seorang guru sebelum mengelola proses pembelajaran. 
Perencanaan pembelajaran merupakan persiapan mengajar yang berisi hal-hal yang perlu atau harus dilakukan oleh guru dan peserta didik dalam melaksanakan kegiatan pembelajaran, yang meliputi pemilihan materi, metode, dan alat evaluasi.

Berkaitan dengan penjelasan yang dimukakan oleh Winarno dan Djuniarto, seharusnya sebagai pendidik yang akan melaksanakan proses pembelajaran dikelas, sudah semestinya pendidik mempersiapkan terlebih dahulu, apa yang harus disiapkan dan dilaksanan pada saat proses pendidikan. Perencanaan merupakan hal yang urgen dalam proses pendidikan, dalam ha ini Rencana Pelaksanaan Pembelajaran (RPP), karna dalam perencanaan ini semua suda tersusun secara sistematis baik materi yang akan diberikan, metode dan juga alat evaluasi untuk mengukur kecapain peserta didik dan juga pendidik dalam mencapai tujuan pembelajaran

Terkait dengan penjelasan diatas maka, peneliti menemukan bahwa kemampuan guru dalam perancangan pembelajaran terlihat cukup baik, hal ini dibuktikan dengan melihat dokumen yang ada, dalam hal ini Rencana Pelaksanaan Pembelajaran (RPP) terlihat cukup baik tersusun secara sistematis dari merumuskan tujuan sampai dengan mengevaluasi hasil belajar, namun antara apa yang tersusun secara sistematis dalam Rencana Pelaksanaan Pembelajaran (RPP) terjadi kesenjangan, dalam artian bahwa apa yang sudah direcanakan tidak terealisai dengan baik pada saat pelaksanaan proses pembelajaran yang dilaksanakan oleh guru IPS, dimana guru hanya menggunakan metode ceramah dan diskusi kelompok, akan tetapi peserta didik kurang mendapat bimbingan dari guru. Selain itu, pelaksanaan proses pembelajaran tidak menekankan pada kebebasan berpikir pada para peserta didik.

Dari penjelasan teori yang dikemukakan oleh Winarno dan Djumniarto (2003) bahwa perencanaan pembelajaran merupakan indikator terpenting dalam melakukan proses pembelajaran terhadap peserta didik. Oleh karena itu kemampuan guru dalam membuat perancangan pembelajaran telah tersusun dengan dengan rapih dan sitematis dalam RPP seyogyanya menjadi acuan dan pedoman bagi guru dalam melaksanakan proses pembelajaran, kemampuan guru dalam merencanakan proses pembelajaran merupakan faktor terpenting dan utama proses pembelajaran.

\section{Pelaksanaan pembelajaran yang mendidik dan dialogis}

Usman H dan Nuryadin ER (2013) menjelaskan bahwa proses pembelajaran tidak hanya menyangkut eksporasi, elaborasi, dan konfirmasi tetapi juga meningkatkan kompetensi siswa dalam melakukan observasi menyimak, melihat, membaca, mendegar, bertanya, asosiasi, menyimpulkan, mengkomunikasikan baik secara lisan, tulisan, maupun bahasa tubuh.

Berkaitan dengan penjelasan teori yang disampaikan oleh Usman H dan Nuryadin ER, bahwa sebagai pendidik dalam melakukan proses pembelajaran, bukan hanya menekankan pada aspek kognitif atau kemampuan peserta didik saja, akan tetapi melalui proses pembelajaran, peserta didik juga mendapatkan nilai-nilai baru yang berkaitan dengan nilai dan norma yang berlaku, karena proses pembelajaran bukan hanya sekedar pemberian materi, tetapi juga mendidk peserta didik (humanisasi). Oleh karena itu, maka, pendidik harus mampu melakukan proses pembelajaran yang mendidik dan dialogis, dalam artian bahwa proses pembelajaran harus terjadi komunikasi aktif antara peserta didik dengan pendidik.

Terkait dengan penjelasan teori di atas, maka guru IPS dalam pelaksanaan pembelajaran yang mendidik dan dialogis sudah dilaksanakan dengan baik, hal ini dapat dibuktikan dengan jawaban yang disampaikan oleh guru bahwa siswa aktif dalam memberikan pertanyaan kepada guru, dan begitu juga peserta didik aktif dalam menjawab pertanyaan yang disampaikan oleh guru. Dan dalam proses pembelajaran, pada saat peserta didik menjawab pertanyaan guru secara tidak benar (salah), maka guru tersebut langsung memberikan koreksi terhadap jawaban 
yang salah dari peserta didik, dengan memberikan arahan dengan memberikan pujian seperti jawaban tersebut benar, tetapi belum terlalu tepat.

Kemampuan guru dalam melaksanakan proses pembelajaran yang besifat mendidik dan dialogis tergolong baik, hal ini dibuktikan pada saat proses pembelajaran berlangsung guru selalu berkomunikasi aktif dengan peserta didik, guru juga memberikan kesempatan yang sama terhadap peserta didik, tidak membeda-bedakan antara peserta didik yang satu dengan yang lainya. Dalam proses pembelajaran juga guru selalu memberikan kebebasan berpikir kepada peserta didik untuk menemukan sendiri solusi dari masalah yang sedang dibahas, guru membentuk kelompok diskusi untuk membahas suatu pokok bahasan, dalam proses diskusi yang dilakukan oleh guru, guru selalu memberikan dorongan, bimbingan kepada peserta didik yang mengalami kesulitan belajar, melakukan pendekatan terhadap peserta didik yang mengalami kesulitan belajar dan memberikan umpan balik terhadap peserta didik agar terlibat aktif dalam proses pembelajaran.

Dengan penjelasan teori yang disampaikan oleh, Usman H dan Nuryadin ER (2013) sejatinya, proses pembelajaran harus berorientasi kepada kebebasan berpikir oleh peserta didik, karena proses pembelajaran tidak hanya menyangkut dengan kemampuann kognitifnya saja melainkan kemampuan afektif, dan psikomotor, dalam artian bahwa proses pembelajaran bukan hanya pemberian materi saja melainkan bagaiman peserta didik dapat memahami dan mengaplikasikan dalam kehidupan sosialnya. Dengan demikian proses pembelajaran yang menekankan pada kebebasan berpikir siswa dengan sendirinya peserta didik akan tumbuh dan berkembang dengan baik mulai dari aspek kognitif, afektif, dan psikomotor.

\section{Evaluasi hasil belajar}

Arikunto (2004) menjelaskan bahwa penilaian dan evaluasi sangatlah penting, baik bagi peserta didik, guru, maupun sekolah. Bagi peserta didik dapat mengetahui sejauh mana telah berhasil mengikuti pelajaran yang diberikan oleh guru, apakah hasilnya memuaskan atau tidak memuaskan. Bagi guru, dapat mengetahui para peserta didik yang sudah dan belum menguasai bahan pembelajaran, tepat atau tidaknya materi pembelajaran yang disampaikan, dan metode yang digunakan. Bagi sekolah, dapat mengetahui apakah kondisi belajar yang diciptakan oleh sekolah sudah dengan harapan atau belum, dan apakah yang dilakukan oleh sekolah sudah memenuhi standar atau belum

Berkaitan dengan penjelasan teori yang disampaikan oleh Arikunto, maka semestinya pendidik dalam melakukan proses pembelajaran, harus mampu juga dalam melakukan evaluasi terhadap hasil belajar peserta didik. Karena evaluasi merupakan hal yang penting dalam prospek pendidikan, melalui evaluasi pendidik dapat mengetahui sejauh mana tingkat pemahan peserta didik terhadap suatu sub-pokok bahasan, evaluai juga juga bukan hanya kepentingan pendidik, tetapi sekolah, yang melalui hasil evaluai ini dapat diketahui sejauh mana kondisi belajar apakah sudah, maksimal atau tidak. Oleh karena itu, maka, evaluasi harus benar-benar diperhatikan pendidik, karena hasil evaluasi dapat memberikan acuan atau pedoman dalam merancang dan melaksanakan proses pembelajaran.

Terkait dengan penjelasan teori di atas, maka, hasil penelitian menunjukan bahwa, guru IPS di SMP Negeri 1 Kabupaten Pulau Morotai yang berkaitan dengan kemampuan guru dalam melakukan evaluasi hasil belajar tergolong baik, hal ini dibuktikan dengan adanya usaha yang dilakukan oleh guru IPS dalam mengevaluasi hasil belajar peserta didik dengan melakukan tes baik tes tertulis maupun tes tidak tertulis (lisan). Guru juga selalu mempertimbangkan hasil temuan untuk dijadikan sebagai pedoman untuk menyusun program pembelajaran selanjutnya, dalam melakukan evaluasi guru juga tidak hanya melakukan evaluasi terhadap peserta didik, tetapi juga melakukan evaluasi terhadap metode dan juga strategi pembelajaran yang 
diterapkan kepada peserta didik, apakah penerapakan dari metode/strategi tersebut dapat mengembangkan potensi peserta didik atau tidak, dan guru juga selalu berupaya dalam melakukan evaluasi terhdapa peserta didik demi mendapat solusi dari permasalahan yang urgen dalam perserta didik terhadap hasil belajar peserta didiknya, sehubungan hal tersebut, $\mathrm{M}$. Chabib Thoha (1990), mendefinisikan "evaluasi merupakan kegiatan yang terencana untuk rnengetahui keadaan objek dengan menggunakan instrumen dan hasilnya dibandingkan dengan tolak ukur untuk memperoleh kesimpulan". Karena pada prinsipnya seorang guru dituntut kemampuan dalam mengevaluasi hasil belajar peserta didik, karena dengan kemampuan mengevaluasi peserta didik, kita dapat mengetahui secara jelas sejauh mana pemahaman peserta didik terhadap materi yang telah diberikan, dan dengan atas dasar temuan dari hasil mengevaluasi itulah yang kemudian guru menjadikan sumber pembelajaran untuk menindaklanjuti berdasarkan temuan yang ada

Dari penjelasan teori yang dijelaskan oleh Arikunto (2004) sejatinya, kemampuan guru dalam mengevaluasi hasil belajar peserta didik merupakan hal yang terpenting dalam proses pendidikan, dengan kemampuan mengevaluasi yang dilakukan oleh guru IPS bukan hanya menguntungkan bagi guru untuk mengetahui sejauh mana pemaham peserta didik terhadap suatu pokok bahasan yang telah dibahas, melainkan juga berpengaruh terhadap guru dalam melakukan perancangan pembelajaran dengan memanfaatkan evaluasi hasil belajar peserta didik.

\section{Kemampuan dalam mengembangkan peserta didik untuk mengaktualisasikan berbagai potensi yang dimilikinya.}

Mengiring keluar (e-ducare) segenap potensi peserta didik agar berkembang, berdaya, dan berguna/bermakna baik bagi diri sendiri maupun bagi orang lain. Berkaitan dengan penjelasan teori yang disampaikan oleh Harefa, maka, sejatinya pendidikan bukan hanya memperhtikan proses, tetapi juga ouput, dalam artian bahwa melalui proses pendidikan peserta didik dapat berkembang baik dari segi kemampuan intelektualnya dan juga moral dari pada peserta didik dapat terbentuk, agar peserta didik dapat bersaing dan mengimplementasikan kemampuannya dalam kanca nasional maupun internasional. Harefa, 2004)

Terkait dengan penjelasan teori di atas, maka hasil penelitian menunjukan bahwa, kemapuan guru dalam mengembangkan peserta didik untuk mengaktualisasikan berbagai potensi yang dimilikinya tergolong cukup optimal, karena dapat dibuktikan dari hasil wawancara bahwa adanya usaha dorongan yang dilakukan oleh guru untuk mengembangkan potensi, atau kemampuan apa yang dimilki oleh peserta didik, dan kemudian membimbing memotivasi serta mengarakan sesuai dengan bakat dan minat yang dimiliki oleh peserta didik, pada saat melakukan proses pembelajaran dengan melatih peserta didik berpikir sendiri menggali informasi sendiri menemukan solusi mengenai masalah dari suatu materi, dan bagi peserta didik yang cenderung pendiam guru melakukan pendekatan maupun memberikan umpan balik terhadap peserta didik agar terlibat secara aktif dalam peroses pembelajaran, guru juga bersifat terbuka dalam proses pembelajaran dalam artian bahwa guru menerima gagasan peserta didik dan membuat proses pembelajaran yang tidak menegangkan sehingga peserta didik terlibat aktif dalam menyampaikan gagasan atau pendapat dari peserta didik.

Dengan penjelasan teori yang disampaikan oleh Harefa (2004) pada Prinsipnya, pengembangan potensi peserta didik merupakan upaya yang sangat penting dalam pendidikan, bahkan menjadi esensi dari usaha pendidikan. Dalam mengembangkan potensi yang dimiliki oleh peserta didik, guru harus melakukan proses pembelajaran yang inovatif dan kreatif, dalam artian bahwa dalam proses belajar mengajar guru harus memberikan kebebasan berpikir kepada peserta didik untuk menemukan, meneganalisis dan mencari solusi dari permasalahan yang

Jurnal Socius: Journal of Sociology Research and Education Vol. 6, No.2, Th. 2019 
ada. Agar peserta didik benar-benar terlatih dalam mengembangkan potensinya pada saat proses pembelajaran

\section{Kesimpulan}

Berdasarkan hasil dan pembahasan hasil penelitian maka dapat disimpulkan sebagai berikut; kemampuan kompetensi pedagogik guru IPS di SMP Negeri 1 Kabupaten Pulau Morotai yang meliputi: 1) Pemahaman terhadap peserta didik, 2) Perancangan pembelajaran, 3) Pelaksanaan pembelajaran yang mendidik dan dialogis, 4) evaluasi hasil belajar, 5) Kemampuan dalam mengembangkan peserta didik untuk mengaktualisasikan berbagai potensi yang dimilikinya, dan dari indikator yang ada pada umumnya sudah dilaksanakan dengan baik. Meskipun demikian, berdasarkan data yang diperoleh masih terdapat beberapa hal yang perlu diperbaiki dan ditingkatkan antara lain: kemampuan memahami karakter peserta didik, kemampuan mengidentifikasikan kesulitan belajar yang dihadapi peserta didik dalam mata pelajaran IPS, kemampuan mengembangkan instrument evaluasi pembelajaran, kemampuan melaksanakan mengimplementasikan rencana pembelajaran dengan menerapkan berbagai metode dan model pembelajaran yang sesuai dengan materi yang akan diajarkan.

\section{Daftar Pustaka}

Arikunto, Suharsimi. (2004). Dasar-dasar Evaluasi Pendidikan. Jakarta: Bumi Aksara

Ahmad Fatah Yasin. (2011). Pengembangan Kompetensi Pedagogik Guru Pendidikan Agama Islam di Madrasah (Studi Kasus di MIN Malang I). Jurnal eL-Qudwah, 1(5), 157

Donal Samuel Slamet Santoso \& Lilis Irawati (2018). Kompentesi Pedagogik Guru SMP Negeri 2 Kaloran Kecamatan Kaloran Kabupaten Temanggung. Skripsi. Pendidikan Ekonomi FKIP Universitas Kristen Satya Wacana.

Djuniarto, Eko dan Winaryo. (2003). Belajar dan Pembelajaran. Jakarta: Rineka Cipta

E Mulyasa. (2009). Standar Kompetensi dan Sertifikasi Guru. Upaya meningkatkan kompetensi dan profesionalisme guru. Jakarta: Bee Media Pustaka

Harefa, Andrias (2004). Membangkitkan Etos Profesionalisme. Jakarta: Gramedia

Mahirah B. (2017). Evaluasi Hasil Belajar Peserta Didik (Siswa), Fakultas Tarbiyah dan Keguruan, UIN Alauddin Makassar Jurnal Idaarah, 1(2), 33-38.

Nur Irwanto. (2016). Kompetensi Pedagogik, untuk peningkatan dan penilaian implementasi kurikulum nasional. Surabaya: Genta Group Production

Sugiyono. (2012). Metode Penelitian Pendidikan Pendekatan Kuantitatif, Kualitatif, dan R\&D. Bandung: Alfabeta

Usman H \& Nuryadin ER. (2013). Strategi Kepemimpinan Pembelajaran Menyongsong Implementasi Kurikulum 2013. Cakrawala pendidikan 32 (1): 1-13

Undang-Undang Nomor 14 Tahun 2015 Tetang Guru dan Dosen

Undang-Undang RI Nomor 20 Tahun 2003, tentang Sistem Pendidikan Nasional 